\title{
Seromucoid, ground substance, and hypothyroidism
}

\author{
ALLAN CAMPBELL, EWAN CAMERON, AND ARTHUR MOLLISON \\ From Coathill Hospital, Coatbridge, Lanarkshire, Vale of Leven Hospital, Alexandria, \\ Dunbartonshire, and the Royal Alexandra Infirmary, Paisley, Renfrewshire
}

SYNOPSIS Seromucoid levels were investigated in four patients with primary hypothyroidism. The administration of L-thyroxine produced a significant and sustained rise in seromucoid concentration above normal. Possible reasons for this response are discussed.

Seromucoid is a heterogenous glycoprotein fraction which accounts for about $10 \%$ of the total serum polysaccharide. Numerous investigators have reported that a rise in seromucoid concentration occurs in certain specific diseases, including cancer (Winzler and Smyth, 1948; Lockey, Anderson, and MacLagan, 1956; Cameron, Campbell, and Plenderleith, 1961 a and b; Cameron, Campbell, and Plenderleith, 1962; Campbell, Graham, and Cameron, 1962; Cameron and Campbell, 1964). Many theories have been advanced to explain the origin of the excess of seromucoid in certain conditions, the most ingenious being that of Gersh and Catchpole (1949) who pestulated an origin from the interstitial ground substance around the proliferating cells.

In a previous study of seromucoid levels in patients admitted to a general hospital, we have recorded that abnormal seromucoid levels occur in patients with advanced myxoedema (Cameron et al., 1961a). Because myxoedema is characterized by an abnormal accumulation of interstitial ground substance which disappears under replacement therapy, it occurred to us that this disease offered an opportunity of investigating the relationship, if any, between seromucoid and ground substance. Seromucoid estimations have been performed in hypothyroid patients under treatment, and this communication records our findings.

\section{CLINICAL MATERIAL}

CASE 1 A woman aged 57 years presented with the classical symptoms and signs of severe myxoedema of at least one year's duration. There was no goitre. Thyroglobulin autoprecipitin tests were negative. Electrocardiography showed the characteristic low-voltage changes of hypothyroidism. There was radiological evidence of cardiac enlargement. The serum cholesterol level was $714 \mathrm{mg} . \%$.

Received for publication 17 February 1964.
CASE 2 A woman aged 55 years presented with the classical symptoms and signs of myxoedema of indefinite duration. There was no goitre. Radio-iodine studies showed a low iodine uptake consistent with hypothyroidism. The serum cholesterol level was $370 \mathrm{mg} . \%$.

CASE 3 A woman aged 30 years developed signs of hypothyroidism while under treatment with methyl thiouracil for primary hyperthyroidism. The diagnosis of hypothyroidism was established on the basis of her clinical appearances and a serum cholesterol level of $450 \mathrm{mg} . \%$.

CASE 4 A woman aged 55 years presented with signs of hypothyroidism, first diagnosed in 1959. Thyroxine therapy had been instituted, but owing to lack of cooperation on the part of the patient, treatment had been discontinued for at least two years before the commencement of this study. The serum cholesterol level was $600 \mathrm{mg} . \%$.

\section{LABORATORY METHODS}

SEROMUCOID Seromucoid ('serum mucoprotein') levels were estimated by a modified Winzler procedure as detailed elsewhere (Cameron et al., 1961a). Seromucoid levels are conveniently expressed as milligram tyrosine equivalents per $100 \mathrm{ml}$. serum (mg. SMT/100 ml.). The normal mean value for seromucoid in this laboratory as determined in a group of 60 healthy controls is $3.5 \pm$ $0.75 \mathrm{mg}$. SMT/100 ml.

UROMUCOID Uromucoid ('urinary mucoprotein') was isolated according to the method of Melo, Mariani, Martirani, and Cintra (1959), the urine being dialysed for 24 hours against water. The perchloric acid-soluble glycoprotein was then precipitated with phosphotungstic acid. The uromucoid precipitate was determined by Folin-Ciocalteau's reagent on the basis of its tyrosine content. Results are also expressed as mg. SMT per 24 hours.

SERUM CHOLESTEROL Serum cholesterol was estimated by Jameson's (1964) modification of the method of 
Pearson, Stern, and McGavack (1953). This is a Liebermann-Buchard method which uses p-toluene sulphonic acid as a colour stabilizer.

All four patients were treated with 1-thyroxine. Seromucoid and serum cholesterol levels were determined at least thrice weekly during the early stages of treatment, and at least weekly thereafter.

\section{RESULTS}

Case 1 was the most extensively studied, and the results of six months' observation are presented in Figure 1. Before treatment commenced, her initial hypothyroid state was associated with a low seromucoid and a high serum cholesterol level. After two months on thyroxine, the patient was free of symptoms and euthyroid in appearance and her serum cholesterol level had dropped to within the normal range. This improvement in her clinical appearance was accompanied by a progressive and sustained rise in the seromucoid level to abnormally high levels.

At this point, thyroxine was withdrawn with the full understanding and consent of the patient. Within a few weeks, clinical signs of hypothyroidism reappeared, accompanied by a steadily falling seromucoid level and rise in cholesterol level. Thyroxine therapy was re-instituted, and her return to a euthyroid state was associated again with an increase in seromucoid as the cholesterol level returned to normal.

Cases 2, 3, and 4 were studied for shorter periods, and the results are shown in Figures 2, 3, and 4. In these three patients it will be noted that the seromucoid concentrations also rose above normal in response to thyroxine therapy. In case 4 , some estimations of urinary mucoprotein output during treatment with thyroxine were performed. It can be seen that changing levels of seromucoid tend to be accompanied by similar changes in the output of urinary mucoprotein.

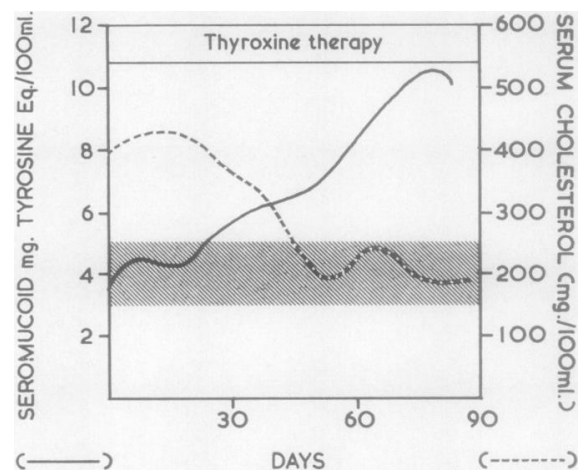

FIG. 2. Case 2. Graph illustrating the persistence of seromucoid elevation after the cholesterol level has reached normal.

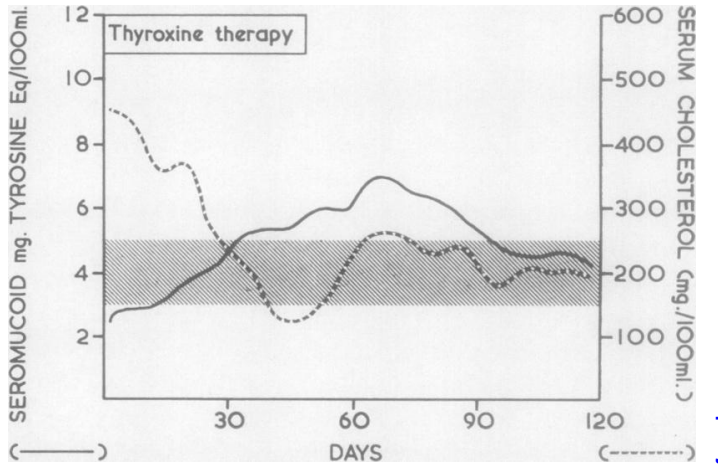

FIG. 3. Case 3. Graph showing the expected elevation of seromucoid and fall in cholesterol level in response to L. thyroxin in a case of hypothyroidism of short duration.

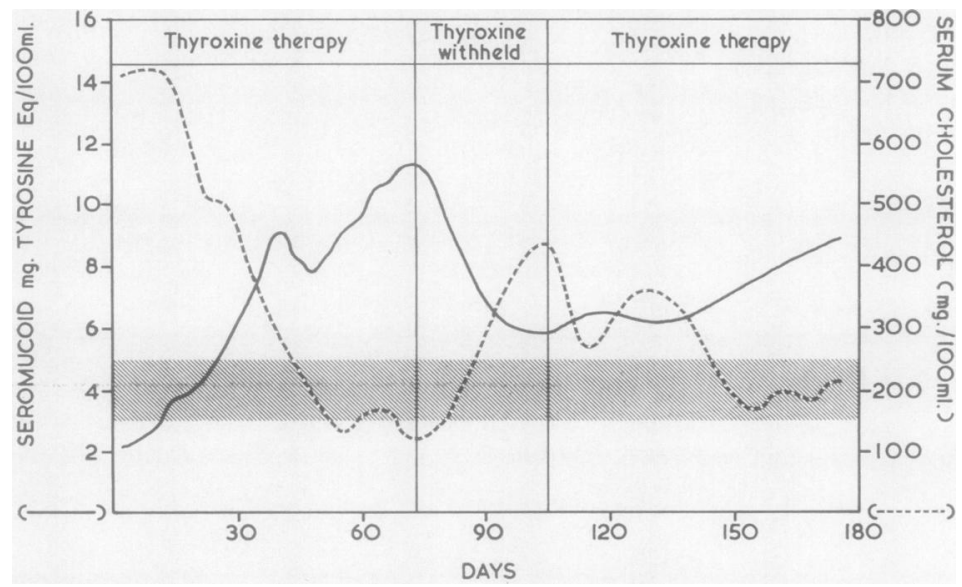

FIG. 1. Case 1. The dependence upon L. thyroxyn therapy for changes in seromucoid and cholesterol levels. 

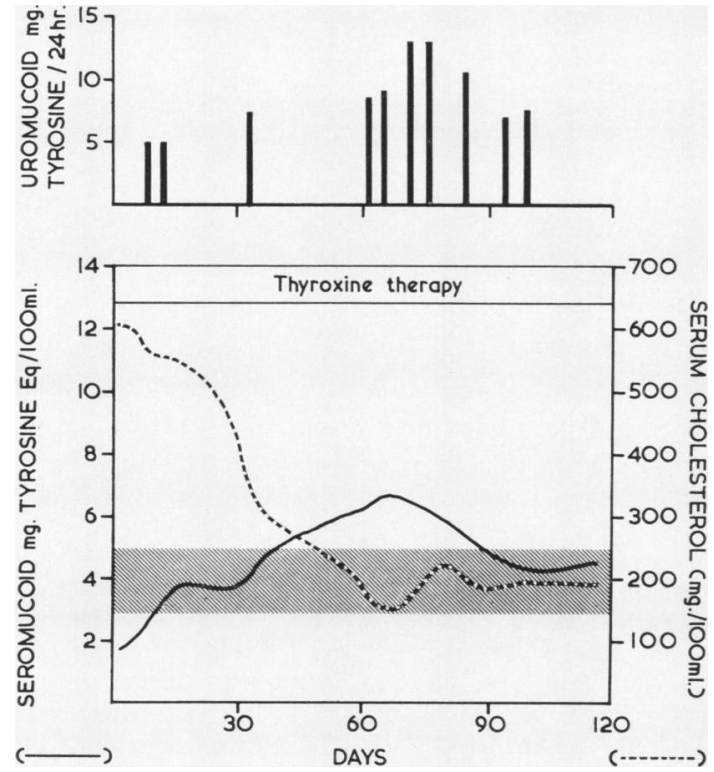

FIG. 4. Case 4. The serial estimation of urinary mucoprotein excretion suggests increased output associated with L. thyroxin-induced seromucoid (serum mucoprotein) elevation.

\section{DISCUSSION}

Our results show that the administration of thyroxine to hypothyroid subjects produces a rise in seromucoid concentration from low to abnormally high values. This rise can be detected soon after starting treatment, and may persist long after the patient is clinically euthyroid. Our investigations suggest that this change in the blood chemistry is associated with an increased urinary excretion of uromucoid, which has been already noted by Melo, Melo, Coelho Neto, Wajchenberg, Martirani, Dias, and Cintra (1963).
Hypothyroidism is characterized by an absolute increase in the amount of the mucopolysaccharide interstitial ground substance, and the return to the euthyroid state under replacement therapy is accompanied by absorption of these excessive ground substance deposits (Watson and Pearce, 1949; Iversen, 1954). It seems reasonable to assume that the changes we have recorded are the result of this increased mobilization of tissue mucopolysaccharide. This finding suggests that the raised seromucoid levels found in other diseases may also have a ground substance origin.

The continued rise of seromucoid is particularly marked in case 1 , in which a raised seromucoid level was still being recorded six months after the commencement of therapy. In severe hypothyroidism all the tissues are heavily infiltrated with mucoid deposits; our findings suggest that in such cases, mobilization and excretion of this material may take many months. Seromucoid estimations carried out at intervals during the course of treatment may be a useful indication of the final return of the tissues to the euthyroid state.

\section{REFERENCES}

Cameron, E., and Campbell, A. (1964). Brit. J. Urology, 36, 257.

$\longrightarrow,-$, and Plenderleith, W. (1961a). Scot. med. J., 6, 301.

$\longrightarrow,-,-(1961 \mathrm{~b})$. Ibid., 6, 308

,,--- (1962). Gut, 3, 260.

Campbell, A., Graham, J. G., and Cameron, E. (1962). Scot. med. J., 7, 472.

Gersh, I., and Catchpole, H. R. (1949). Amer. J. Anat., 85, 457.

Iversen, K. (1954). In Connective Tissue in Health and Disease, edited by G. Asboe-Hansen, pp. 130-150. Munksgaard, Copenhagen.

Jameson, A. (1964). Personal communication.

Lockey, E., Anderson, A. J., and MacLagan, N. F. (1956). Brit. J. Cancer, 10, 209.

Melo, E. H. L., Mariani, I., Martirani, I., and Cintra, A. B. U. (1959). J. Lab. clin. Med., 54, 739.

-, Melo, I. M., Coelho Neto, A., Wajchenberg, B. L., Martirani, I., Dias, J. C., and Cintra, A.B. de U. (1963). J. clin. Endocr., 23, 561 .

Pearson, S. Stern, S., and McGavack, T. (1953). Anal. Chem., 25, 813. Watson, E. M., and Pearce, R. H. (1949). Amer. J. clin. Path., 19, 442. Winzler, R. J., and Smyth, I. M. (1948). J. clin. Invest., 27, 617. 